\title{
Ethics constructed through the process of nurse training: conceptions, spaces and strategies ${ }^{1}$
}

\author{
Flávia Regina de Souza Ramos ${ }^{2}$ \\ Laura Cavalcanti de Farias Brehmer ${ }^{3}$ \\ Mara Ambrosina de Oliveira Vargas ${ }^{4}$ \\ Dulcinéia Ghizoni Schneider ${ }^{5}$ \\ Laila Crespo Drago ${ }^{6}$
}

Objective: to discuss the professors' conceptions about the ethical dimension of nurse training based on the relationships which this establishes with the competencies with the professional profile; and to identify the spaces and strategies for the teaching of ethics in this process. Method: A qualitative study delineated as a case study. The data was collected based on focus groups with professors from six undergraduate nursing courses in the state of Santa Catarina, Brazil, totaling 50 subjects. Based on the professors' discourse, the conceptions and mutual relations between professional competencies, the formative process and ethics were analyzed. Results: The results were organized and the discussion explored through the thematic categories: The ethics constructed in the process of training nurses - the professors' conceptions, and spaces and strategies for the teaching of ethics in nurse training. Conclusions: The issue of ethics was shown to be transversal in the formative process. The study evidenced the challenge of creating spaces and strategies for teaching and fosters discussion about the new demands for changes placed upon the nursing schools, about the suitability of the care setting, and about the exercising of critical and problem-based education.

Descriptors: Education Nursing; Nursing Education Research; Ethics.

${ }^{1}$ Supported by Conselho Nacional de Desenvolvimento Científico e Tecnológico (CNPq).

2 PhD, Associate Professor, Departamento de Enfermagem, Universidade Federal de Santa Catarina, Brasil.

${ }^{3}$ Doctoral Student, Departamento de Enfermagem, Universidade Federal de Santa Catarina, Brasil.

${ }^{4} \mathrm{PhD}$, Adjunct Professor, Departamento de Enfermagem, Universidade Federal de Santa Catarina, Brasil.

5 PhD, Professor, Universidade do Sul de Santa Catarina, Brasil.

${ }^{6}$ RN, Scholarship holder PIBIC CNPq/UFSC, 2010-2012.

Corresponding Author:

Flávia Regina Souza Ramos

Universidade Federal de Santa Catarina

Departamento de Enfermagem. Campus João Davi Ferreira Lima

Bairro Trindade

CEP: 88040-900, Florianópolis, SC, Brasi

E-mail: flaviar@ccs.ufsc.br 


\title{
A ética que se constrói no processo de formação de enfermeiros: concepções, espaços e estratégias
}

Objetivo: discutir as concepções de professores sobre a dimensão ética da formação do enfermeiro, com base nas relações estabelecidas entre ética, competências e perfil profissional, bem como identificar os espaços e estratégias para o ensino da ética nesse processo de formação. Método: estudo qualitativo, delineado como estudo de caso. Os dados foram coletados entre grupos focais, com professores de seis cursos de graduação de enfermagem de uma universidade do Estado de Santa Catariana, totalizando 50 sujeitos. Tomando-se como base o discurso dos professores, foram analisadas as concepções e mútuas relações entre competências profissionais, processo formativo e ética. Resultados: os resultados foram organizados e exploram a discussão acerca das categorias temáticas: a ética que se constrói no processo de formação de enfermeiros, as concepções de professores e espaços e estratégias para o ensino da ética na formação em enfermagem. Conclusões: o tema da ética mostrou-se transversal no processo formativo. O estudo evidenciou o desafio de se criar espaços e estratégias de ensino e fomenta a discussão acerca das novas demandas por mudanças colocadas às escolas, da qualificação do cenário do cuidado e do exercício da educação problematizadora e crítica.

Descritores: Educação em Enfermagem; Pesquisa em Educação de Enfermagem; Ética.

\section{La ética que se construye en el proceso de formación de enfermeros: concepciones, espacios y estrategias}

\begin{abstract}
Objetivo: Discutir las concepciones de los profesores sobre la dimensión ética de la formación del enfermero, a partir de las relaciones que establece con las competencias del perfil profesional; e identificar los espacios y estrategias para la enseñanza de la ética. Métodos: Estudio cualitativo delineado como estudio de caso. Los datos fueron obtenidos a partir de grupos focales, con profesores de seis cursos de pregrado en Enfermería del estado de Santa Catarina, totalizando 50 sujetos. Resultados: Los resultados fueran organizados y exploran la discusión de dos categorías temáticas: La ética que construye en el proceso de formación en enfermería - las concepciones de profesores y Los espacios y estrategias para la enseñanza de la ética en la formación de enfermería. Conclusiones: La ética se mostró transversal en el proceso formativo. El estudio mostró el reto de desarrollar espacios y estrategias de enseñanza y sus contribuciones fueron la discusión sobre las nuevas demandas por cambios presentadas a las escuelas y sobre la cualificación del escenario del cuidado y del ejercicio de la educación problematizadora y crítica.
\end{abstract}

Descriptores: Educación en Enfermería; Investigación en Educación en Enfermería; Ética.

\section{Introduction}

The teaching of ethics in the training of nurses represents an essential sphere in the construction of the role of the future professionals. Ethical questions permeate the personal experiences and the personal experiences in the teaching and work settings, deserving attention which contemplates the doubts and conflicts inherent to the formative process. The lecturers are responsible for providing spaces and constructing strategies which give visibility to ethics throughout the training period and which promote ethical reflection based on practical problems.
Undergraduate nursing courses in Brazil define the profile of a graduate as a professional who is capable of articulating intervention competencies in health care services in his or her role as a social actor in the context of public health policies. Critical thinking is expected of the professional in taking ethical and moral decisions ${ }^{(1)}$.

The teaching of ethics in courses in nursing and the area of health can not be structured without an understanding of the social context(2) or of the criticisms of the ways of organizing or offering health care or of how the profession should respond to these demands. 
This study is part of an investigation which sought to analyze the discursive construction of ethics in nursing training, present in processes of curricular changes. The present study had the aim of discussing the professors' conceptions about the ethical dimension of nurse training based on the relationships which this establishes, with the competencies and with the professional profile, as well as identifying the spaces and strategies for the teaching of ethics in the process of nurse training.

In choosing discursive construction, the study is inspired in the Foucaultian notion, according to which texts and oral expressions are taken as manifestations of discourses, while being potential operators of social practices, putting into action and operating knowledges and multiple forms of intervention, that is to say, strategies of power which circulate in the social life. Discursive elements do not reduce to the textual sphere, as, at the same time as they are architectured by thoughts they also construct ways of thinking and acting. The authors' study objects are, thus, immersed in these discourses and practices and it is this which lends them meaning(3). By this means, the textual data (oral and documental) are not restricted to the variables or elements described in the content, as they are the substance itself of critical reflection.

\section{Method}

This is qualitative research delineated as a case study, selected due to its utility in social research, because it focuses on contemporaneous phenomena and seeks to understand "how" specific processes or experiences develop; especially when the frontiers between object and phenomenon are not clearly distinct. In this case, it was a multiple case study, which strengthens the method and its findings and allows the units of analysis to be addressed in the combination of all the cases studied ${ }^{(4)}$.

The data was collected in 2008 and 2009, through focus groups, run by the principal researcher in six undergraduate courses in the state of Santa Catarina, Brazil, and selected for their distribution in all the geographical regions of the state and for having been in existence for a minimum of six years. The subjects were these institutions' nursing professors, invited to participate due to their interest in the issue (without having to be professor of ethics). Contact was made through the course coordinator and a total of 50 professors participated, with numbers per group varying from 05 to 15 .
All ethical aspects were respected, in accordance with Resolution CNS 196/1996. The study was approved by the Federal University of Santa Catarina's Committee for Ethics in Research involving Human Beings, under decision 075/07.

The discussions which developed in the groups were transcribed and organized with the help of the Atlas-Ti 5.0 software (Qualitative Research and Solutions). Firstly, the entire discursive text was broken down into excerpts or "codes"; these received identification according to their meaning or the element which grouped to the general theme (pre-categorization); these categories were later grouped by their capacity to constitute a discursive unit, exploring facets or insights of the central unit - the discursive construction of ethics in nurse training. This object or macro unit can be divided into units incorporated to the analysis, independent of origin in any of the cases or research contexts. Four of these incorporated discursive units are explored in the present article, addressing the professors' conceptions (about professional competencies, the formative process, and ethics) and the spaces and strategies for teaching ethics.

The results are presented in the form of discursive summaries, not taken in reference to collective discourses or specific methods of analysis, but only for summarizing of the findings in units of relevancy, capable of interpretation.

\section{Results}

The two objectives of the study are aimed at discussion, based on the discourse and on the experience of the participating professor, on the conceptions and spaces and strategies constructed for ethics in nursing training. These two foci are presented in four statements which synthesize the content expressed by the subjects and take in four sub-categories, three relative to the conceptions ( $\mathrm{A} 1 \mathrm{~A} 2$ and $\mathrm{A} 3$ ) and one relative to the spaces and strategies for teaching ethics in the training (B).

The ethics which are constructed in the process of nurse training - the professors' conceptions ( $A 1, A 2$ and $\mathrm{A} 3$ ).

\section{A1 - Ethics is constructed and manifests itself in one's relationship with oneself and with others, assuming respect for plurality, responsibility in professional action and confidence in the care relationship}

I can't see a way out for the profession, unless it is each independent being positioning him or herself so that in the future there can be a summarizing [...] and we keep talking 
about the profession's lack of unity.[...] I've been working a lot on self-care... of really self-examining, self-perceiving. Making your choices and being responsible for your choices. (P4).

I compare ethics to blindness. I tell the students that being ethical is having a conscience. - The forceps fell on the ground, and only you saw? You have to tell the professor, - I'm not going to use this [...] in ethics, he [the other] is blind, he has to be able to rely on you, he has no eyes, but [the right thing] has to happen, in all the relationships.(P3).

A2 - Ethical competency is intrinsically linked to professional competency, it integrates different work capacities or dimensions and a component of individual positioning which expresses the profession

[...] it needs one more support to move on, just one side, just the personal side and the relationships don't make a nurse, you need a foundation to arrive and sign underneath what you're going to do. (P3).

It's a question of perceiving that the nurse, in this world of work, is different. That she is going to have to be capable of being a good educator, a good technician, maybe a good scientist, a good researcher. (P2).

A3 - The formative process is obtained in the relations with work, in such a way that this incorporates the ethical training in different experiences and is also modified by openness to dialog and to the other

Is it trying to change peoples' heads? I don't think so! We have to hope there will be an internal conflict, to have the responsibility of creating people with ethics, who enjoy having more open thoughts [...] That professional who knows how to deal with the uncertainty, who can be flexible with technology, more than just being critical... that he can be seeking solutions. (P1).

What's central is the contextualized professional, inserted into the team and current public policies [...] It's central to exercise citizenship, this professional is to construct the professional space, act as such and occupy a political space in this local reality. (P5).

\section{B - Spaces and strategies for the teaching of ethics in nursing training}

Ethics occupies different spaces in the formative process. The discussions about ethical questions carry over between the times allocated for this purpose and the various experiences which permeate the process.

In the first phase we enter with ethics to try to instrumentalize the students [...] we always try to do it based on practical things which the students themselves bring, and make them notice $[\ldots]$ (P4).

Despite being organized in specific content, by convention ethics is indicated by professors as a transversal theme which permeates the entire process of training the undergraduate nursing students. In this way, the inclusion of discussions on ethics in all the topics of theory and practice is configured as a principal teaching strategy.

[...] it isn't like it's one day, one content created in ethical teaching, rather, it permeates the entire process. (P2).

And the discussion on this issue specifically appears in various moments of this period, on some specific issues, some specific situations, experienced as scientific knowledge or even in some situations experienced in the field with students. There are situations where you have to consider this important issue and bring it to the day-to-day of the course and try to produce something strategic in relation to this. (P4).

Care for yourself, for others and for the setting. Because we have to be concerned about the environmental question too, even, with the home and the community (P7).

\section{Discussion}

The accounts which make up statement A1 indicate the importance of the future professional's positioning and ethical and moral commitment. Hence, they evidence the need to induce in the student an ethical reflection conceived in two types of inalienable relationships, in the relationship with oneself and with others. In the first, self-knowledge and care for oneself are assumed as part of professional responsibility and professional performance. In the ethics which is constructed and manifested in the relationship with others, it is assumed there is respect for diversity, plurality and a new way of understanding the truth. It is also an expression of individual choices and, therefore, is linked to responsibility for acts and their consequences.

In this direction, Foucault focalizes the elaboration of ethical work which each person effects on themselves, not only to make their own behavior conform to a preestablished rule, but also to try to transform themselves into moral subjects through their own attitude ${ }^{(5)}$. The philosopher speaks of an Ethics of attitude, strongly articulated with the technical and political instrumentalization(6).

Thus contextualized, ethics and politics are constituted in the epicenter of all the relationships. Which relationships? Relations of power/government of oneself and of others/relation of oneself with oneself. 
Relations which make up a chain, a scheme, and which in the confluence of these articulate with the question of politics and of ethics. They are relations which insert the subject in the world, which instrumentalize him or her to deal with happenings, and make each one seek to act as they ought. Far from isolating the subject from the human community, it appears, on the contrary, as that which articulates him or her to it. Relations which must allow him or her to be an ethical subject citizen of the world(5).

From the contexts of the personal and family experiences of the students spaces are also delineated where ethical questions appear which may be discussed in any moment during the training. The recognition of oneself in situations with the other or in examples of theoretical reflection occurs when it is motivated by similar experiences or because its own values lead to the exercising of the imagination about the ethical implications.

The discussions about ethical issues are among those which adjust to the teaching process of innumerable disciplines, as usually surprises the professors responsible, because of the positive repercussion among the students. In this regard, a Canadian study and another from South Korea showed, respectively, education as a promoter of the attitude for interdisciplinary work and ethics appeared as one of the issues which was most suited to interprofessional education. Both evidenced that the study of ethics and/or the discussion of ethical content in the training represents, for the students, the development of moral reasoning and the comprehension of the relationship between decision-taking and professional competency ${ }^{(7-8)}$.

The approximation, let us say academic, with the study of Ethics, usually, begins with the deontological norms which reflect nursing practice committed to Ethics $^{(9)}$. However, in this process of training of the student, one should conduct it to transcend the logic of a responsibility restricted to a meaning of ethics which is professional, civil or penal, like obligation, a charge, a commitment or a duty to act in line with a convention to be satisfied or implemented ${ }^{(5)}$. That is, acting must widen the dimension of the responsibility when the actions' results will influence other people's health and lives. It must be recognized that the nurse has a shared responsibility and must also answer for acts practiced under his or her supervision, whether direct or indirect. Hence the nurse must, more than anybody else, promote reflection and the capacity to take the correct decision and action in the care context(10).
In addition to this, the responsibility demands that the subject has freedom of choice in his or her actions, which implies not only being able to distinguish good from bad, justice from injustice, but, above all, being able to act in accordance with values which he or she chose him or herself. There can be no ethical attitude without autonomy, even if the professional should share the values and accept the regulations of his or her profession, accepting, tacitly, the responsibilities which legitimate it socially(11-12).

To sum up, the exercising of autonomy leads the nurses to face ethical problems and the consequent need to take complex decisions, which demand adaptation to ethical principles and values in general and of the profession in particular. The autonomy must be reflected in any decision-making, inevitably linked to the capacity, to the obligation, and to the commitment and social mandate that the professional takes on ${ }^{(13)}$.

The statement $A 2$ directs the discussion to the representation of the nurse's ethical training as an important challenge for professionals and researchers, especially because ethical demands are in the core of the relationships between education and work. Such a challenge may be taken from the point of view of the competencies, profiles, projects and pedagogical strategies, as well as the problems experienced in the real work contexts, demanding reflection on how the ethical dimension is expressed in the everyday of the formative experience.

The conception of professional competence is intrinsically linked to that of ethical competence, because this articulates the different competencies necessary or activated in professional activity. The construction of professional competency takes place in the effort by balancing (in the training) the diversity of fields of action, of duties or dimensions of work, valuing each one of them - the care, the management, the education and the research. The difference of the nurse in the collective work is identified in this multidimensionality and in the capacity to get the best out of this - to put oneself as a new and qualified professional into a context of changes and growing demands. This "putting oneself" in the real context of work takes the feeling of a positioning. Positioning indicates creating resonances in the whole work context, through the capacity to defend positions and argue for them, without losing the opening for the search for new knowledge.

Studies $^{(14-17)}$ have demonstrated that nursing education must focus on integral care, constructed based on critical-reflective references in the definition of the 
area of professional competencies; the lecturers need to extend their ethical knowledge beyond normative and deontological aspects; the application of educative methodologies entails the reframing of the lecturer's pedagogical training, to train nurses in a discourse/ action which is proximal between theory/practice, which equips them for citizenship, for ethics and politics, and to care for society; and the development of competencies grounded in ethical-political values will contribute to producing sensible citizens, able to act in the spheres of care, management and education, collaborating in the construction of health policies.

It is necessary to pause on the question of competency to deal with ethical problems in health. The moral or ethical dilemmas occur when there are different perspectives on the same situation and this places the individual between two opposing propositions. This takes in situations in which moral or ethical values are in conflict and the decision in favor of one option invalidates the other ${ }^{(18)}$. It is noteworthy that the ethical reflection obliges the subject to choose, to seek and to problematize between the various possible solutions, which are those which correspond not only to criteria of efficiency and efficacy, but to the balance between costs and benefits, above all the demands of priority, equity and morality.

One way of supporting professionals in dealing with ethical problems (which extrapolate the dilemmatic situations) is contextualized education in ethics. This involves a clear understanding of the work and, because of this, the competency equivalent to the comprehension of what is being done and of the context in which their work is inserted, that is, it is important to value the subject, his or her workplace, and the peculiarities of both $^{(19)}$.

The statement $A 3$ reports the question of whether a professional nurse needs to be strongly inserted in the process of health care. The professional training is conceived of as being strictly related to the work, in all its complexity, multiple interactions and experiences. This presupposes a permanent interweaving, in the educative process, of discourses, values and principles, as well as spaces and opportunities constructed by the subjects' actions, for reflection and dialog. Such opening to the other as a subject is a condition for ethical training to produce educative relations differentiated in all moments, including in the evaluation. But, personal and subjective conflict is, also, a mobilizing factor or access path or Ethics.
There is, also, a challenge of constructing a new professional identity, which breaks with traditional models. Even adopting a humanist conception and the valuing of the relational dimension of the work (demanding emotional intelligence), it must be capable of overcoming the normatized and what is in place as the work space. This means reconfiguring such work spaces, making oneself available to confront and position as a subject of transformation of real contexts.

For the undertaking of changes in training professionals as promoters of citizenship, in oneself and in others, it is necessary to understand the ethical dimension of valuing the human being added to health, as an outstanding motivator of other values. Thus, creating knowledge becomes a wider process, on which the professional education needs to reconstruct its role and re-encounter its space in the ethical training of the professional, as knowledge, attitudes, and above all the nurses' behaviors are increasingly important in nursing care and health and in the achieving of results(20-21).

In this regard, the framework of ethics as a discipline limits all the possibilities of exploring spaces which are constructed in the process of training with the interaction of professor and students and of these with the scenarios in the classroom, the world of care and the world of work. Because of this, ethics instituted in the curriculum as a discipline cannot reach the moral development of the student. Ethical training is constituted in a complex and embracing process, inserted in all the disciplines in a transversal way in all the course content ${ }^{(1)}$.

The perception of a discussion of ethics in a transversal form to the process was shown and constituted Statement B. Three different ambits emerged from the professors' accounts, which constituted potential spaces for encouraging ethical reflections during the training of students: the ambit of institutional relations, the ambit of relations with the community, and the ambit of relations with the students, in the context of their personal life.

It is principally questions articulated to the limited vision of power centered on the institutional hierarchy that arise from institutional relations. The relationships between students and professors, nurses and other health workers represent the configuration of potential spaces for the arising of ethical questions to be discussed.

The values permeate all the relations which are established in the process of nursing training, through the daily contact between lecturers and students and other professionals with service users and the community ${ }^{(22)}$. 
When the students begin to interact in real work scenarios, in addition to in institutional relationships, they start to build relationships with the health service users, with the family, and with the community. Innumerable examples of ethical implications can emerge from this approximation. The student enters the real world of life, health, suffering, and social, economic and cultural differences. He or she seeks to apply theory to practice and runs into the challenges of reality.

The theoretical-practical fragmentation of the ethical dimension of care was evidenced as a fragility found in the process of training. Gaps persist between the theoretical content and the actions in practical experiences. This paradox confounds and hinders the overcoming of the challenges of training governed by ethics ${ }^{(23)}$.

These ambits were referenced as spaces over and above the formal periods, determined by the curriculums and teaching plans. In these spaces, ethics is addressed more from the theoretical perspective and approaches practice only timidly. It takes place in a verticalized manner; the content is presented, and the students do not demonstrate familiarity with the issues. However, this differentiation must not denote any sort of value judgment, both the ethical approach based on disciplines and the discussions which arise from the experiences in practice are essential elements in the training. It is appropriate to reaffirm the complementarity between the theoretical content and the approximation with the demands arising from the students' experiences and relationships.

The introduction of ethics, as well as bio-ethics, into curricular disciplines, arises from the interpretation of the guidelines and recommendations proposed by the National Curricular Directives for Undergraduate Nursing Courses (DCENF), Resolution CNE/SES 03 of $7^{\text {th }}$ November 2001. Based on the DCENF, a process was started of restructuring the curricular, didactic and pedagogic organization, directed at changing the process of training nurses. This process is to be permeated by the ethical dimension of routine activities, constructed based on critical thinking, reflection, social analysis and subjects' relationships in a concrete reality. otherwise, any strategy of change based on the DCENF would be abstract and inadequate(22).

One strategy used by professors to encourage the discussion of ethical questions, with positive results, has been the problematization of practice experiences. These are real examples, experienced by the students and which take on a more concrete feeling for reflection.
Thus, the professors receive the challenge of surpassing the teaching strategy based in the transmission of values and norms and advance to dialog, with reallife experiences as background, articulating ethics and ethical practice in the academic setting(24).

The teaching of ethics, although a discipline of the process of nursing training, is necessarily articulated with practice to attribute meaning and promote critical reflection. The adoption of active methodologies for approaching real problems of the everyday has been configured as one of the possibilities for training nurses ${ }^{(25)}$.

The lecturers are challenged to make the students' experiences significant, beyond a technical rationality and articulating scientific knowledge and sensitive knowledge ${ }^{(26)}$.

The offer of a variety of experiences in the process of training comprises one of the perspectives for inserting ethics into the teaching agenda. The more possibilities there are for experiencing the different care spaces, the more the possibility increases for the student to experience situations which demand actions or reflection supported by knowledge of professional ethics and of ethics as a field of knowledge. Strategies were indicated for teaching ethics whose boundaries surpass the teaching of professional ethics. The teaching of bioethics, of ethics from the perspective of other disciplines such as philosophy and sociology, environmental ethics and ethics in research involving human beings and animals are examples of how to broaden the ethical debate in the training and to cover other aspects of the students' lives.

The scenario of changes in professional training in health, specifically in the nursing courses, gathers together objects which are fundamental for a wider discussion of the issue. They are elements of macro dimensions, such as globalization and the information society or the national context of public health or education policies. In the face of these elements, professors and students are inserted in this dynamic and confront situations imposed by the same. It is from this universe that situations emerge for ethical debate and the construction of critical and reflexive thinking in $\operatorname{academia}^{(27)}$.

\section{Final considerations}

Brazilian nursing is in an intense process of change, above all in the educational field. The effort for producing impacts in the training of nurses qualified to work in 
the Unified Health System* and the consolidation of public policies is revealed, also, in the valuation of the ethical dimension of the relationship between work and education. Professors are important actors in this process and express the conflicts between guidelines, values and institutional and personal principles, permanently updated in the pedagogic routine and in the teachingwork integration. The conceptions which conform these professors' discourse and practice allow advances in the problematization of the experiences in construction.

The study reaffirmed the complementarity between the theoretical contents, identified by the narrow relation with the issue of ethics, and the demands and problems recognized in the experiences and accounts of the students in the practice field. The care setting is the principal space for ethical training, showing itself as in permanent construction. Ethics has become a concern of the professors', overarching all the moments of the formative process and challenging them to seek new references and to re-elaborate more problematizing and critical teaching strategies.

The effervescence of the issues which emerged from the everyday of the professor in this study represents the strengthening of the discussion of the praxis of nursing. Despite the limits recognized of an empirical research project, it is noteworthy that the same has to gather meaning to educative and professional practice, as well as encouraging the search for innovative experiences for ethical training, in strong adherence to the care setting's demands. In this regard, the study bolsters the knowledge produced concerning the relationship between education, ethics and qualified professional care, as well as the importance of instrumentalizing professors and educative practices directed at ethical competencies.

\section{References}

1. Ferreira HM, Ramos LH. Diretrizes curriculares para o ensino da ética na graduação em enfermagem. Acta Paul Enferm. 2006;19(3):328-31.

2. Germano RM. A Evolução do Ensino da Ética para Enfermeiros. Rev Bioética. [periódico na Internet];2009; [acesso 27 jul 2011]; 4(1). Disponível em: http:// revistabioetica.cfm.org.br/index.php/revista_bioetica/ article/view/399/362

3. Foucault M. A arqueologia do saber. $7^{a}$ ed. Rio de Janeiro: Forense; 2009.
4. Yin RK. Estudo de Caso: planejamento e métodos. $4^{a}$ ed. Porto Alegre: Bookman; 2010.

5. Foucault M. A hermenêutica do sujeito. São Paulo: Martins Fontes; 2006.

6. Vargas MAO, Ramos FRS. Autonomia na unidade de terapia intensiva: comecemos por cuidar de nós. Rev Bras Enferm. 2010;63(6):956-63.

7. Vernon $R$, Curran DRD, Fleet L. Academic administrators' attitudes towards interprofessional education in Canadian schools of health professional education. Canada J Interprofessional Care. 2005; Supplement 1:76-86.

8. Park M, Kjervik D, Crandell J, Oermann MH. The relationship of ethics education to moral sensitivity and moral reasoning skills of nursing students. Nurs Ethics. [periódico na Internet]. 2012. [acesso 26 mai 2012]; 19(4):568-80. Disponível em: http://nej.sagepub.com/ content/19/4/568.short

9. Rosenkoetter MM, Milstead JA. A code of ethics for nurse educators: revised. Nurs Ethics. [periódico na Internet]. 2010. [acesso 26 mai 2012]; 17(1): 137-9. Disponível em: http://nej.sagepub.com/content/17/1/137

10. Ramos FRS, Schneider DG, Vargas MAO, Brito MJM. Ética no gerenciamento em enfermagem. Programa de Atualização em Enfermagem Gestão, do Sistema de Educação Continuada em Saúde Continuada a Distância (SESCAD). Ciclo 1. Porto Alegre: Artmed- Panamericana Editora; 2011.

11. Schneider DG, Ramos FRS. Moral deliberation and nursing ethics cases: Elements of a methodological proposal. Nurs Ethics. [periódico na Internet]. 2012. [acesso 26 jun 2012]; Disponível em: http://nej.sagepub. com/content/early/2012/05/04/0969733011420096. full.pdf+html

12. Schneider DG, Ramos FRS. Processos éticos de enfermagem no Estado de Santa Catarina: caracterização de elementos fáticos. Rev. Latino-Am. Enfermagem. [periódico na Internet]. 2012. [acesso 26 mai 2012]; 20(4):744-52. Disponível em: http://www.scielo.br/ pdf/rlae/v20n4/15.pdf

13. Ribeiro JMS. Autonomia profissional dos enfermeiros. Rev Enferm Referência. 2011;3(5):27-36.

14. Silva KL, Sena RR. A educação de enfermagem: buscando a formação crítico reflexiva e as competências profissionais. Rev. Latino-Am. Enfermagem. [periódico na Internet]. 2006. [acesso 02 mai 2012]; 14(5): 574-84. Disponível em: http://www. scielo.br/scielo.php?script=sci_arttext\&pid=S0104-

* The Brazilian State Health Service. Translator's note. 
$11692006000500018 \&$ Ing =en\&nrm=iso\&tlng=pt

15. Mascarenhas NB, Rosa DOS. Bioética e formação do enfermeiro: uma interface necessária. Texto Contexto Enferm. 2010; 19(2): 366-71.

16. Nunes ECDA, Silva LWS, Pires EPOR. O ensino superior de enfermagem: implicações da formação profissional para o cuidado transpessoal. Rev Latino-Am Enferm. [periódico na Internet]. 2011. [acesso 30 jun 2012]; 19(2):252-60. Disponível em: $\quad$ http://www.scielo.br/scielo.php?pid=S010411692011000200005\&script=sci_arttext\&tlng=pt 17 . Santos AS, Araujo EA. A competência e os aspectos ético-políticos no curso de enfermagem: a partir do olhar de docentes enfermeiros. ConScientiae Saúde. 2008;7(1):93-100.

18. Dalmolin, GL, Lunardi VL, Barlen ELD, Silveira RS . Implicações do sofrimento moral para os(as) enfermeiros(as) e aproximações com o Burnout. Texto contexto - enferm. [periódico na Internet]. 2012. [acesso 18 mai 2012]; 21(1): 200-8. Disponível em: http://www.scielo.br/scielo.php?pid=S010407072012000100023\&script=sci_arttext

19. Sporrong SK, Arnetz B, Hansson MG, Westerholm $P$, Höglund AT. Developing ethical competence in health care organizations. Nurs Ethics. 2007;14(6):825-37. 20. Pinheiro PNC, Marques MFC, Barroso MGT. Ética na formação profissional - uma reflexão. Esc Anna Nery. 2006;10(1):116-20.

21. Wu Y, Deng Y, Zhang Y. Knowledge, attitudes, and behaviors of nursing professionals and students in Beijing toward cardiovascular disease risk reduction. Nurs Health. [periódico na Internet]. 2011. [acesso 28 mai 2012]. Disponível em: http://www.ncbi.nlm.nih. gov/pubmed/21412801.

22. Fernandes JD, Rosa DOS, Vieira TT, Sadigursky D. Dimensão ética do fazer cotidiano no processo de formação do enfermeiro. Rev Esc Enferm USP. [periódico na Internet]. 2008. [acesso 28 mai 2012]; 42(2): 396-403. Disponível em: http://www. scielo.br/scielo.php?script $=$ sci_arttext $\&$ pid $=$ S0080$62342008000200026 \&$ Ing $=$ en\&nrm $=$ iso\&tlng $=p t$

23. Bordignon SS, Lunardi VL, Dalmolin G de L, Tomaschewski JG, Lunardi WD Filho, et al. Questões éticas do cotidiano profissional e a formação do enfermeiro. Rev Enferm UERJ. 2011;19(1):94-9.

24. Graciano, RDM; Badim, MPM. A influência da ética na enfermagem. Eisntein: Educ Contin Saúde. 2009;(1Pt. 2):37-8.
25. Mascarenhas NB, Rosa DOS. Bioética e formação do enfermeiro: uma interface necessária. Texto Contexto-Enferm. [periódico na Internet]. 2010. [acesso 1 mai 2012]; 19(2): 366-71. Disponível em: http://www.scielo.br/scielo.php?script=sci_arttext\&pid =S0104-07072010000200019

26. Terra MG, Gonçalves LHT, Santos EKA, Erdmann AL. Sensibilidade nas relações e interações entre ensinar e aprender a ser e fazer enfermagem. Rev. Latino-Am. Enfermagem. [periódico na Internet]. 2010. [acesso 26 mai 2012]; 18(2): 203-9. Disponível em: http://www. scielo.br/pdf/rlae/v18n2/pt_10.pdf

27. Ramos FRS, Borges LM, Brehmer LCF, Silveira LR. Formação ética do enfermeiro - indicativos de mudança na percepção dos professores. Acta Paul Enferm. $2011 ; 24(4): 485-92$. 